\title{
Tax Risk Management for Taxpayers After the Omnibus Law in Indonesia
}

\author{
Laina*, Burhan* \\ * Master of Administration Science Students - TAX Management - Institute STIAMI, Indonesia \\ Email : \\ lielaina@gmail.com \& Burhanchen456@gmail.com
}

DOI: 10.29322/IJSRP.11.07.2021.p11573

http://dx.doi.org/10.29322/IJSRP.11.07.2021.p11573

\begin{abstract}
Abstrak - The COVID-19 pandemic has changed the development and economic and social order throughout the world; this pandemic disrupts human health and soul and disrupts the economy and stability of the country's financial system. This Covid-19 effect has become a catalyst, where the existence of this covid pandemic puts tremendous pressure on the Indonesian economy and makes the Indonesian government take quick steps to save the recession. This expansionary fiscal policy is the primary option taken by the government in the form of significant spending and relaxation of collections to save the economy so that it can survive. This expansionary fiscal policy will affect fiscal consolidation. To balance this expansionary and consolidative fiscal policy, the government took steps to revise various tax regulations by carrying out various tax rule reforms to minimize future fiscal risks after a deep contraction due to the Covid-19 Pandemic. The momentum of economic recovery will also determine tax revenue for the following year; economic recovery will require better budget resilience. In this context, the government needs new sources of revenue, particularly from the tax sector. The omnibus law, which was ratified at the end of 2020, is a post-demic preparation for economic recovery. Changes in several fundamental aspects of tax reform have been included in the Job Creation Law. However, the tax regulation reform agenda does not stop there; the government continues to carry out policy reforms by looking at the needs and dynamics of the taxation world, which will give birth to Valotile regulation. In this case, the essential thing for taxpayers is to investigate the risk of tax management and its effect on taxpayers.
\end{abstract}

Keywords: Tax Policy, fiscal consolidation, economic recovery, Tax Reform, Omnibus Law, Risk management

\section{Introduction}

The year 2020 is challenging; the global economy, including Indonesia, is experiencing uncertainty and the threat of an economic recession in many countries due to the Covid-19 pandemic. This pandemic threatens world health and impacts the Indonesian economy and even the world, making the government postpone the strategic plans that had been set initially, then replaced them with emergency response policies by mobilizing all resources to overcome the Covid-19 outbreak. The Covid-19 pandemic not only affects the health crisis but also has a significant impact on the economy. Various drastic changes in the socio-economic life of the community have changed the pattern of trade in the world, even in Indonesia. Some industries experienced a deep downturn, others benefited from the disaster, but the economy has experienced a reasonably deep contraction in Indonesia. The government has taken extraordinary policy strategies and steps to save the national economy and financial system stability through various relaxation policies related to implementing the State Revenue and Expenditure Budget (APBN), particularly by increasing health and economic recovery spending. The initial step in this extraordinary period is for the government to issue a Government Regulation instead of Law Number 1 of 2020 concerning State Financial Policy and Financial System Stability for Handling the 2019 Corona Virus Disease (COVID-19) Pandemic and In Facing Threats That Endanger the National Economy. And Financial System Stability. This Perppu contains various state financial policies, including the taxation and financial sectors, to save the economy from the downturn due to the Covid-19 pandemic.

The primary fiscal policies adopted by the government in 2020 are various tax incentives and adjustments to the State Budget. The provision of tax incentives is intended so that the corporate sector can have room to breathe during a problematic situation. When the pandemic is pressing, the Indonesian government encourages relaxation by providing stimuli such as PPH 21 borne by the government, Accelerating restitution with the aim of not disrupting corporate cash flow, PPh UMKM borne by the government, reduced instalments, and even stimulus for specific business fields affected by the pandemic. One example is a company engaged in the automotive sector with a $0 \%$ sales tax on luxury goods for new cars. The expansionary fiscal policy is often used as an option by various countries. This policy aims to save the economy, and this expansionary policy risks increasing debt, interest rates, and inflation rates. 
ISSN 2250-3153

At the same time, in adjusting the APBN, the government has revised its APBN and provided an allocation of funds which is great to overcome this corona outbreak. The Revised State Budget has been amended several times, including changing the tax revenue target. Changes in revenue targets with the latest amendment to Presidential Regulation (Perpres) number 72 of 2020, namely a decrease in tax revenue target by $27.02 \%$ to IDR $1,198.82$ trillion from the previous target $1,642.57$ trillion. (2020)

The Covid-19 pandemic that occurred in 2020 was also the driving force behind the passing of the Omnibus Law. When the state needed a budget in handling the pandemic, this pandemic has weakened the economy to increase economic growth by increasing investment and employment. The Indonesian government ratified the Omnibus Law, known as the Job Creation Act, on November 2, 2020.

No one knows how long this pandemic will last, how deep its impact will have on the socio-economic-public health aspects, and how to determine the economic prospects this year and the year to come. For this reason, the 2021 State Budget takes the theme "Accelerating Economic Recovery and Strengthening Reforms". (KEMENKEU, 2021)

The government plans to extend the tax stimulus to continue until the end of 2021, significant spending and relaxation of tax collection will undoubtedly make the budget deficit bigger, the government needs to be aware of financial risks and maintain the resilience of the budget deficit, so the government must concentrate on how to maintain budget resilience by optimizing revenue and targeted policy reforms. The government's policy scenario for the recovery of the national economy during this pandemic in the macroeconomic framework is as follows: First, economic recovery from the impact of the Covid-19 pandemic, the policy is carried out by accelerating the recovery of the business world affected by the Covid-19 pandemic and continuing the handling of health recovery and social protection. Second, increasing economic competitiveness is taken by increasing economic competitiveness by encouraging increased innovation and technological adaptation capacity. Third, demographic conditions are a policy to increase employment opportunities to increase short-term economic growth. Fourth, continue reforms aimed at maintaining the sustainability of structural reforms to support medium and long-term economic growth. Fifth, the acceleration of economic transformation is intended to accelerate the transformation of the manufacturing industry and encourage Indonesian manufacturing products with hightech products. Moreover, fifth, get out of the middle-income trap. The middle-income trap is the failure of a country to upgrade from lower-middle-income to upper-middle-income. Indonesia will gradually get out of the middle-income trap by improving productivity, increasing competitiveness, and improving the quality of human resources (especially labour). (YULIANTO, 2020)

Following the 2021 State Budget theme, for now, strengthening reform is the government's concern; tax reform must be right on target so as not to distort the economy. The very dynamic development of the times can affect tax collection in meeting the needs of the state. For this reason, it is essential to implement tax reform. In preparation for the post-pandemic, many countries compete in tax rate competitions intending to attract investment and end up with tax reform. When many reforms and rapid changes lead to an asymmetric understanding of taxes, this will have profound implications for taxpayers because regulations become dynamic and change quickly. Omnibus law"?

\section{Literature Review}

\section{The main points of fiscal policy in Indonesia during the Covid-19}

The spread of COVID-19 poses a severe challenge to financial sector stability due to investor concerns about the spread of COVID-19 and its profound impact on the global economy. In the real sector, pressures occur on both the demand and supply sides, which will suppress economic growth. The decline in economic activity creates the threat of termination of employment which results in a decrease in people's income which in turn has implications for consumption levels. Production activities were also hampered as supply chains, distribution flows were disrupted, and decreased investment. The COVID-19 pandemic has occurred, but uncertainty about when the pandemic will end makes projecting the economic outlook challenges.

Tax is a vital State instrument. In essence, there are two tax functions for the state, namely:

1. The function of Buggetair, namely as a source of state revenue;

2. Regular function, namely as a government tool to regulate economic growth through tax policy

Through this Regularend function, the government can make tax policies in tax incentives for business actors in stimulating the economy. The role of the government is the key to the success of handling this pandemic; it takes an appropriate policy to maintain economic stability.

1.

\section{GOVERNMENT REGULATION IN LIEU OF LAW (PERPU) No. 1/2020 (LAW NO. 2 the YEAR 2020)}

The implications of the Covid-19 pandemic have also had an impact on the threat of the financial system. It is necessary to take steps to deal with the risk of macroeconomic and financial system instability.

Therefore, adequate legal instruments are needed to provide a solid foundation for the government and related institutions to make such policies and measures. Therefore, President Joko Widodo issued Perpu No.1/2020.

This Government regulation in lieu of law No. 1/2020 also regulates four policies in the field of taxation as follows: 1. Adjustment of income tax rates $(\mathrm{PPh})$ for domestic corporate taxpayers and permanent establishments (BUT). 
2. Tax treatment in trading activities through the electronic system (PMSE).

3. Extension of time for the exercise of rights and fulfilment of tax obligations.

4. Granting authority to the Minister of Finance to provide customs facilities in the form of exemption or relief from import duties for handling emergency conditions and restoring and strengthening the national economy.

The primary material of Government Regulation in Lieu of Law (Perppu) 1 of 2020 includes 2 (two) policies, namely the State Finance Policy including the taxation sector and the Financial Sector Policy.

\section{STATE BUDGET REVENUE ADJUSTMENT POLICY (APBN)}

Disruption of economic activity will have implications for changes in the posture of the State Budget for the 2020 fiscal year, both state revenues, state expenditures, and the financing side. State financial and fiscal policy responses are needed to deal with the risks of the Covid-19 pandemic.

In order to ensure the availability of the budget while maintaining the health and sustainability of state finances, the government stipulates changes to the Posture and Details of the State Revenue and Expenditure Budget for the Fiscal year 2020.

This change in posture and details of the 2020 State Budget was stipulated by Presidential Regulation of the Republic of Indonesia Number 54 of 2020 dated April 3, 2020, namely a decrease in tax revenue by $23.65 \%$ to IDR $1,254.11$ trillion from the previous target of 1,642.57 trillion. The Presidential Regulation is to implement the provisions in Government Regulation in Lieu of Law (Perppu) Number 1 of 2020 concerning State Financial Policy and Financial System Stability for handling Covid-19 and facing threats that endanger the national economy and financial system.

The government then stipulates Presidential Decree 72 of 2020 as a replacement for Presidential Regulation 54 of 2020 on June 24, 2020; Presidential Regulation 72/2020 is stipulated based on considerations to maintain the quality and sustainability of the State Revenue and Expenditure Budget for Fiscal Year 2020 in order to meet the needs of handling the Corona Virus (COVID-19) pandemic and facing threats that endanger the national economy and financial system stability. Changes in Presidential Regulation 72 of 2020 are revisions to the Posture and Details of the State Revenue and Expenditure Budget for the Fiscal Year

2020. It was replaced by a decrease in the target of tax revenue by $27.02 \%$ to IDR $1,198.82$ trillion from the previous target of $1,642.57$ trillion.

\section{TAX INCENTIVE POLICY}

This regulation is present as the government's answer to prevent conditions from getting worse, and there are four incentive points given:

1. Individual Income Tax(PPH 21 incentives

In the form of income tax borne by the government on income (salary) received by employees who have a tax base number, the gross income is fixed and does not exceed Rp. 200,000,000 per year.

2. Import Income Tax (PPH 22 Import) incentives

The government exempts import income tax (PPH 22) from companies with specific criteria.

3. Income Tax Installment (PPH 25) Reduction incentive

Income Tax Article 25 will receive incentives by reducing the number of instalments by $50 \%$ of the total instalments that should be paid. Article 25 income tax is included in this regulation because many business actors have begun to reduce their activities or even temporarily stop their business as long as this epidemic has not stopped.

5. Value Added Tax Refund Incentive

For VAT, the treatment of incentives is different from the previous three types of taxes. The VAT incentive provided is the ease of the process of granting restitution to PKP. There is a difference in the nominal limit for restitution given to PKP Exporters and PKP Non-Exporters. For PKP acting as an exporter, there is no nominal limit for VAT that will be refunded, while for PKP, NonExporters are given accelerated restitution with a maximum value of 5 billion rupiahs.

\section{STAMP DUTY POLICY}

Changes in the stamp duty are made after approximately 35 years have not changed, it is necessary with consideration of optimizing state revenues, providing legal certainty in collecting stamp duty, adjusting to the needs of the community, implementing the imposition of stamp duty more fairly and aligning the provisions of the stamp duty with the provisions of other laws and regulations.

\section{OMNIBUS LAW POLICY (JOB CREATION LAW)}


The Indonesian government ratifies the Job Creation Law or what we usually call the Omnibus Law. The establishment and ratification of this law aim to simplify several regulations to attract investors and create jobs in Indonesia. The ratification of the omnibus law is following the President's Vision in 5 years of leadership (2019-2024), according to the presidential speech at the inauguration ceremony on October 20, 2019. development.

The changes contained in the Job Creation Law are expected to encourage the birth of new businesses for the nation's economic

\section{Tax changes in Job creation law}

There are several clusters regulated in this law, including the taxation cluster. However, not all tax-related Omnibuses are included in the Job Creation Law. Some are included in Regulation in Lieu of Law (Perppu) No. 1/2020, which was also passed into Law no. 2/2020 regarding State Financial Policy and Financial System Stability for Handling the 2019 Corona Virus Disease (Covid19) Pandemic.

Tax clusters in the Job Creation Law are contained in Chapter IV related to investment and ease of doing business which has not been listed in Law no. 2/2020.

The main goal of the Taxation Cluster is the ease of doing business which includes four pillars, namely: ((https://uuciptakerja.go.id/wp-content/uploads/2020/11/Klaster-Kemudahan-Berusaha-Bidang-Perpajakan.pdf, 2020), 2020)

1. Increase investment funding;

2. Encouraging taxpayer compliance and voluntary compliance;

3. Increasing legal certainty;

4. Creating a fair business climate in the country.

\section{Increase Investment Funding}

1. Gradual reduction in Corporate Income Tax rates; 22\% (2020 and 2021) and 20\% (2022 and beyond). - has been regulated in Law no. $2 / 2020-$

2. Reduction of corporate income tax rates and Go Public Taxpayers (general rate - 3\%). - has been regulated in Law no. 2/2020-

3. Elimination of Income Tax on Dividends from within the country.

4. Certain income (including dividends) from abroad is not subject to income tax as long as it is invested in Indonesia.

5. The profit share of the cooperative and the Hajj Fund managed by BPKH is a non-tax object

6. Space for Adjustment of Article 26 Income Tax Rate on Interest.

7. Equity participation in the form of assets is not subject to VAT.

\section{Encouraging taxpayer compliance and voluntary compliance}

1. Relaxation of Input Tax Crediting Rights for Taxable Entrepreneurs.

2. Reset: a. Tax Administrative Sanctions, b. Interest Reward

\section{Increasing legal certainty}

1. Determination of Individual Tax Subjects: a. Indonesian Citizens and Foreign Citizens who stay> 183 days in Indonesia are subject to Domestic Tax, b. Imposition of Income Tax for Foreign Citizens who are Domestic Tax Subjects with specific expertise only on income from Indonesia, c. Indonesian citizens in Indonesia for $<183$ days can become Foreign Tax Subjects with certain conditions.

2. Delivery of coal includes delivery of Taxable Goods.

3. Consignment does not include delivery of Taxable Goods.

4. Income tax on excess funds from Social \& Religious Agencies (such as Educational Institutions) is a non-tax object

5. Tax penalties that have been decided are no longer issued tax assessments.

6. The deadline for the issuance of the Tax Collection Letter is five years. Tax invoices can be issued to collect interest compensation that should not be given.

\section{Creating a fair business climate in the country}

1. Taxation of Electronic Transactions: a. appointment of a platform to collect VAT, b. imposition of taxes on foreign tax subjects on electronic transactions in Indonesia. - has been regulated in Law no. 2/2020-

2. Inclusion of the NIK of buyers who do not have NPWP in the Tax Invoice.

There are four articles of tax law in the Job Creation Law that regulate:

1. Income Tax $(\mathrm{PPh})$

2. Value Added Tax (PPN) and Sales Tax on Luxury Goods (PPnBM) 
3. General Provisions and Tax Procedures (KUP)

4. Regional Taxes and Levies (PDRD)

\section{Income Tax Change}

- If in Law no. $2 / 2020$ there is a gradual decrease in income tax up to $20 \%$ in 2023 , the decrease in income tax is also contained in this job creation law.

- Income in the form of dividends for Individual Taxpayers (WPOP) originating from within and outside the country to be invested in Indonesia will not be taxed.

- The condition is that dividends and income invested are at least 30\% of the profit after tax, and the shares of the Corporate Taxpayer (WP Badan) are not traded on the Indonesian stock exchange.

- This is stated in Article 4 paragraph (3) letter $\mathrm{f}$ of the Job Creation Law.

- Provisions on tax collection for Indonesian citizens residing abroad and foreigners residing in Indonesia have also changed.

- Foreigners who are in the country for 183 days and do business or earn income in the jurisdiction of Indonesia will be subject to

Domestic Tax so that they will be subject to Domestic Income Tax.

- On the other hand, if an Indonesian citizen is abroad for 183 days and conducts business in another country, his status will be subject to Foreign Tax (SPLN) and subject to Foreign Income Tax.

- Indonesian citizens and foreigners as tax subjects are regulated in Article 2 paragraph (4) letters a, b, c, d.

\section{Changes in Value Added Tax and Luxury Sales Tax}

- Article 112 of the Job Creation Law contains regulations for relaxing VAT and VAT input tax credits.

- In this article, a Taxable Entrepreneur (PKP) who has not submitted goods or services for export can credit the input tax as long as it fulfils the crediting according to the law.

- In the previous regulation in article 9 paragraph (2a) of the PPN and PPnBM Law, PKPs that have not yet produced can credit their input tax.

- If within three years the company delivers the goods, a tax credit can be made.

- However, if there is no delivery of goods or services, input taxes in specific sectors of goods or services cannot be credited.

- In specific sectors, a period longer than three years may be granted.

\section{Changes in General Provisions and Tax Procedures (KUP)}

The Job Creation Law also revised the provisions for sanctions from reporting and paying taxes.

The rules that have changed are:

1. The reduction in sanctions for late reporting of SPT and underpayment of taxes is adjusted to the level or rate of the reference interest rate per month, which was previously stated in the KUP Law of $2 \%$ per month.

As a result of this new calculation, the number could be lower than the previous sanctions.

a. Sanctions of fines based on the reference interest rate plus 5\% divided by 12 shall apply on the date of starting the calculation of sanctions, for a maximum of 24 months for Taxpayers (WP) who;

- Self-correcting the tax return and making the tax debt bigger

- Underpayment due to correction of Annual/Monthly Notification letter (SPT Tahunan/ SPT Masa)

- Late payment of Income Tax Article 29 of the annual notification letter (SPT Tahunan)

- Late payment of monthly notification letter (SPT Masa)

b. The penalty is based on the reference interest rate plus $10 \%$ divided by 12 , for a maximum of 24 months, if the underpaid tax return is not paid.

c. The penalty is based on the reference interest rate plus $15 \%$ divided by 12 , for a maximum of 24 months, if you do not pay the underpaid tax and get an underpaid tax assessment letter (SKPKB).

2. If the Taxpayer does not submit the SPT or fills in the SPT incorrectly or incompletely, or attaches information whose contents are incorrect, he will be fined $100 \%$ of the amount of tax underpaid when the disclosure of tax reporting is incorrect. This amount is lower than what is written in the Law on General Provisions of Taxation, $150 \%$.

3. If PPh PKP is underpaid, the administrative sanction in the form of interest determined by the Minister of Finance is calculated from the time the tax becomes due or the end of the Tax Period, part of the Fiscal Year, or Fiscal Year until the issuance of a Tax Collection Letter (STP).

4. The Taxable Entrepreneur does not issue an invoice or issues an incomplete invoice, subject to a $1 \%$ sanction from the Tax Imposition Basis (DPP).

5. Tax Collection Letter for late payment of the Additional Underpayment Tax Assessment Letter (SKPKBT), Correction Assessment Letter, Objection, Appeal, and Resubmission Assessment, interest penalty for delaying payment due to instalments, and interest on the lesser amount of deferred Tax Collection Letter, subject to interest sanctions per month following the provisions of the Minister of Finance based on the reference interest rate divided by 12 for a maximum of 24 months.

6. Termination of the investigation of tax crimes is carried out after the taxpayer has paid off the tax debt that is not/underpaid/should be returned, plus an administrative penalty of 3 times the amount of tax that is not/underpaid/should be returned. 
ISSN 2250-3153

Amendments to the Law on Regional Taxes and Levies (PDRT)

In addition, to facilitate business licensing, the central government, in this case, the Minister of Finance, will evaluate the draft regional regulations and existing regional regulations related to PDRD.

\section{Tax Payer Risk Management}

Tax management is planning, organizing, directing, and controlling resources to make payment of taxes owed effectively and efficiently. Effective means that the goal of tax savings can be achieved following the tax planning that has been made and determined. Efficient means that the existing tasks are carried out correctly, organized, and following the plans that have been decided (H. Prianto Budi S., 2016)

Tax risk management for taxpayers is an effort by taxpayers or business actors to reduce the risk of administrative sanctions or tax disputes in their tax compliance obligations. Tax risk management is an important thing that needs to get the attention of business actors and create added value for business actors.

Especially during the Covid-19 pandemic, taxpayers should make a scheme to mitigate the impact of risks that may occur, such as operations, marketing, finance, and taxation.

Many countries are competing in tax policy reforms; the Indonesian government also attracts investment and maintains the economy. Changes in several fundamental aspects of tax reform have been included in the Job Creation Law. However, the Tax Reform Agenda in Indonesia will continue to roll after the enactment of the Omnibus Law (UU Cipakerja). Volatile regulation.

In this case, taxpayers need to deal with the risk of tax management on the volatility of the regulation by continuing to follow the development of regulatory changes and see changes and their broad impact.

\section{The Importance of Tax Risk Management after the Copyright Act}

1. Taxpayers are expected to evaluate policy changes after the Omnibus Law during this pandemic so that they can take into account the impacts that will arise in the business that will be or is being undertaken.

2. Taxpayers are sought to understand the taxation strategy during the pandemic and its implementation to integrate the regulations and the taxpayer's obligations.

3. Taxpayers can create a system that can identify tax risks due to volatility in tax regulations during the pandemic and post-Omnibus law. It also allows taxpayers to make a risk assessment, so you can quickly issue internal policies on the tax burden incurred.

As we know, the impact of the Covid-19 pandemic is terrible for all parties; the government touches every aspect, business people when economic activity declines, for internal companies, it is essential to pay attention to tax risk management because it can provide convenience for every stakeholder.

\section{Conclusion}

In general, the Covid-19 pandemic has impacted almost all sectors, impacting world health and having a severe impact on the domestic and even global economic sectors. The significant impact on the domestic economy is the decline in people's purchasing power; the decline in purchasing power reflects the contraction in consumption and investment. The decline in purchasing power is the leading cause of the slowdown in economic growth. The government continues to strive to continue to reduce the negative impact of the coronavirus outbreak on the wheels of the national economy. In its fiscal policy, the government provides fiscal stimulus, which is to maintain the purchasing power and continuity of business actors with the ultimate goal of saving the economic recession. This expansionary fiscal policy affects the resilience of the government's budget, so the government needs to take consolidative policy steps, which is a policy that will reduce the budget deficit by optimizing revenue, especially in the taxation sector. Many countries are competing in tax rate competition intending to attract investment and will end up with tax reform, which is also the case in Indonesia. One of the controversial steps taken by the government is to ratify the job creation law or known as the Omnibus law. Tax reform not only stops until the job creation law; in the future, there will be many tax reforms. One example of Tax Reform in the field of VAT, if viewed from the experiences of previous economic crises, when the economy recovers, tax revenues that recover the fastest are consumption-based taxes, in Indonesia, the tax is called 'VAT', so do not be surprised if later it will require many tax reforms in the area of VAT. There will be many changes to tax regulations after the work creation law is passed. The government's concern is that rapid and sweet changes will lead to an asymmetric understanding of taxes; this will profoundly affect taxpayers. It is not surprising that regulatory policies during this pandemic may not apply or change later in the post-pandemic period. To avoid this impact, taxpayers need to implement tax risk management to avoid tax disputes in the future. Taxpayers must continue to follow the development of regulatory changes and see changes and impacts widely and identify risks that may occur so that taxpayers can issue internal policies 
on the tax burden incurred.

\section{References}

H. Prianto Budi S., A. C. (2016). Manajemen Pajak. Jakarta: PT. Pratama Indomitra Konsultan. https://uu-ciptakerja.go.id/wp-content/uploads/2020/11/Klaster-Kemudahan-Berusaha-Bidang-Perpajakan.pdf. (2020). KEMENKEU. (2021). APBN 2021. KEMENKEU.

prastowo, Y. (2017, March 17). Retrieved January 12, 2021, from https://www.online-pajak.com/tentang-efiling/modernisasiadministrasi-perpajakan-upaya-penyempurnaan-pelayanan-pajak-bagian-1-1

YULIANTO, H. (2020). In PROBLEMATIKA EJONOMI DAN PANDEMI COVID-19. PROGRAM DOKTOR ILMU EKONOMI FEB-UNHAS.

\section{Author}

- Laina, Master of Administration Science Students - TAX Management - Institute STIAMI, Indonesia, lielaina@gmail.com

- Burhan, Master of Administration Science Students - TAX Management - Institute STIAMI, Indonesia, burhanchen456@gmail.com 